\title{
No Southern Comfort: Three Georgia Colleges and the New Normal in Higher Education
}

\author{
Matthew R. Hodgman ${ }^{1, *}$ \\ ${ }^{1}$ Dept. of General Education, Goodwin College, 1 Riverside Drive, East Hartford, CT, 06118, \\ USA \\ *Correspondence: Dept. of General Education, Goodwin College, 1 Riverside Drive, East \\ Hartford, CT, 06118, USA. Tel: 1-860-528-4111. E-mail: mhodgman@goodwin.edu
}

Received: August 12, 2014 Accepted: August 21, 2014 Published: September 8, 2014

doi:10.5296/ije.v6i3.6126ＵRL: http://dx.doi.org/10.5296/ije.v6i3.6126

\begin{abstract}
American institutions of higher education currently face a myriad of new challenges as a result of recessions and larger macroeconomic issues. Current changes to the higher education landscape include: increased enrollments by underrepresented and non-traditional student populations; the emergence of an increasingly prominent for-profit sector of higher education; decreased state funding for higher education; increased tuition costs; the need to balance teaching and research; lingering questions surrounding accountability and governance, and reductions in need-based financial aid to students. In short, colleges and universities are being asked to do more with less thus creating a new normal state of existence for higher education. This article traces three Georgia colleges (Georgia State University, Georgia Perimeter College, and Agnes Scott College) through the circumstances and challenges presented by the new normal state of higher education. Suggestions surrounding how each college might continue to navigate difficult circumstances are offered. Issues such as completion, student debt, diversity, performance-based funding, tuition policy, accountability, globalization, and college readiness are discussed within the context of each institution and within the greater need to increase quality at a time where institutional resources are increasingly scant.
\end{abstract}

Keywords: Higher Education, Funding, Completion, Governance, Accountability 


\section{Introduction}

Over the past decade, higher education enrollments have grown rapidly while state and local funding for higher education have declined due to recessions. The 2008 recession dealt a major blow to per-student support while enrollments grew by $12.5 \%$ between 2008 and 2011 (SHEEO, 2011). Increasingly, as economic conditions remain poor colleges and universities have been forced to find ways to do more with less; this state of reality can be deemed 'the new normal” in higher education. In the wake of recessions and larger macro-economic challenges (e.g. retirement and health care costs driving up the cost of higher education) facing the U.S., higher education has been pushed to creatively (and at times, seemingly impossibly) reduce student attrition, reduce the cost of instruction and time to a degree, while improving instruction and student experiences, balancing teaching and research, and increasing the numbers of students who graduate and find meaningful work in their areas of study. This new-fangled predicament cannot be ignored. Schools must assume that government support (certainly state support) for higher education will not rebound and accordingly put forth effective plans to increase productivity and diversity with less funding without compromising quality or risk falling by the academic wayside. With this said, it is clear that a new mode of thinking is necessary to guide higher education through current turbulence and promulgate it to more efficient and effective levels of operation. Themes of operating support for higher education, productivity, completion, student debt, diversity, performance-based funding, tuition policy, accountability, globalization, and college readiness will continue to dominate higher education discussions (AASCU, 2012). The changing relationship between the state government and higher education requires a new relationship between these parties to be forged that pays deference to both institutional autonomy and academic freedom on one hand and state involvement and societal needs on the other. What is needed is a revised social contract; a reworked relationship between higher education and the government that is constructive for both entities, one that is bilaterally mindful and respectful of current realities (i.e. escalating demands, economic constraints, the academy's resistance to change, and the instability of political leadership) (McGuinness Jr., 2011).

It is also important to note that changing student demographics comprise another aspect of the new normal. The current generation of college students is the most racially and ethnically diverse in U.S. history; much of this growth in diversity can be linked to increased access for non-traditional students in particular higher education sectors. For example, over the last 30 years the percentage of women attending college has increased, the percentage of whites has decreased, and 3 times more Hispanics have enrolled in colleges and universities (Renn \& Reason, 2012). Some of these demographic shifts are endemic to particular institution types. For example, private two and four year institutions saw a $44 \%$ increase in enrollment between 2000 and 2008 whereas public institutions saw an increase of only 19\% (Renn \& Reason, 2012). Much of the enrollment increases for underrepresented non-traditional students has been consolidated to public and private two year institutions, particularly for-profit colleges (Kinser, 2006; Ruch, 2001).

Other characteristics of college students have changed. For example: significant increases in 
adult learners have been noted; students are generally working more while attending college; enrollment patterns for veterans have been unpredictable; first-generation students remain a large segment of the undergraduate college population; current students are more team-oriented, achievement-oriented, spiritual, civic-minded, politically polarized, progressive about race and lifestyles, and pressured to succeed than students of previous generations; while an enrollment gap still exists for lower-income students (Renn \& Reason, 2012). These demographic realities need to be carefully considered by higher education policy-makers, administrators, and faculty when attempting to improve the current state of educational opportunities and experiences on campus; there is no uniform or "average" college student or experience (Goldrick-Rab \& Cook, 2011, p. 271). The current developing globalized and pluralistic society demands that higher education leaders think intentionally about diversity if they want their institutions to remain credible or viable; reframing diversity as essential to institutional excellence is now imperative (Smith, 2011, p. 475).

In relation to diversity, leaders will need to consider the interconnectedness of state funding declines, privatization, access, diversity, and success. For example, unless sufficient needs-based financial aid is provided, low-income students and underrepresented populations may be excluded from participation in higher education; poverty may be the biggest barrier to college attendance and completion. Non-need based merit aid (which disproportionately aids middle- and upper-class students) rose from $10 \%$ of state grant dollars in the early 1990 s to nearly one-quarter in 2002; this impacts low-income students who are less willing to incur large amounts of debt to finance college and may not be eligible for merit aid (Zusman, 2005).

Financial support is not likely to be enough to guarantee access and success in college as college preparation issues weigh down underrepresented students in areas where schools have scant academic resources and potentially lower expectations for students. This implores leaders to consider who should be responsible for college preparation. Do schools simply need to attract higher quality teachers to K-12 settings? Should higher education actively work with low-resource schools to advocate for increased resources and student readiness? Should colleges assume the responsibility to provide remedial education for students who are not adequately prepared for college success? Regardless of how these questions are answered, schools need to do a better job of preparing students for college and help students consider whether college is a good and reasonable option (Baum, 2012; Gelber, 2007).

Increasingly, higher education is being viewed as a private good. A growing proportion of the public believes that students should pay more of their colleges costs (Zusman, 2005). As colleges and universities become increasingly privatized (nationally, state funds for all public institutions dropped from 46\% of current fund revenues in 1981 to 36\% in 2000), a debate pertaining to who benefits from a college education burns (Zusman, 2005). This is not simply an either/or debate as both society and the student benefit from higher education economically and socially (Baum \& McPherson, 2011). However, as college access increases taxpayers have a legitimate claim to see positive outcomes from subsidizing higher education. As higher education transits from mass to universal access, the previous access debate has shifted to an attainment/completion debate. Questions surrounding who pays for (e.g. 
students, business, the public), who benefits from (e.g. society, individuals), and who decides the fate of higher education (e.g. accountability, governance, and coordination) have assumed center stage in the $21^{\text {st }}$ century (Schmidtlein \& Berdahl, 2011; Zusman, 2005).

\section{Three Georgia Colleges under New Normal Conditions}

The University System of Georgia (USG) has not been immune to the consequences of the economic downturn and the exigent need to do more with less during the new normal in higher education. While the challenges facing Georgia Perimeter College (GPC), Georgia State University (GSU), and Agnes Scott College (ASC) may differ along institutional type lines, all three schools must contend with many of the issues endemic to a recession and endemic to the current state of higher education in general as articulated above. Atlanta has been hit hard by the economic downturn: an 11\% unemployment rate ( 2 points higher than the national average); massive home foreclosures; increases in students working part-time jobs; stagnating faculty salaries; and business closures have brought economic issues, stress, anxiety, and other mental-health problems to Atlanta-area residents, students, and employees (Biemiller, 2011). Since the 2007 recession, Atlanta has experienced the fourth-highest private sector job losses in American cities going from 2,133,300 jobs in 2007 to 1,925,100 jobs in 2011, a nearly 10\% decline (Atlanta Business Chronicle, 2011). Although businesses in America's 100 biggest markets have reduced their workforces by 4.5 million employees since 2007, clearly the impact has been particularly severe in the Atlanta area (Atlanta Business Chronicle, 2011). In this recession climate, students in the greater Atlanta area will likely need increased economic assistance to make attending college a reality, this will be challenging for schools to provide given the new normal conditions, particularly as college applications and enrollments rapidly increase during recession periods. Recession also means that state budgets will become even tighter thus limiting funds to colleges which support operating costs, student success, and infrastructure upgrades such as the construction limits/academic space issues at GPC that are difficult to address during a recession (Biemiller, 2011). On the other hand, increased student enrollment translates to increases in revenue which have helped GPC hire 30 new tenure-track faculty (Biemiller, 2011).

Before other relevant issues are analyzed, background on each of the three schools must be given. Georgia Perimeter College (1964) is two-year associate degree-granting (in addition to two bachelor's offerings) unit of the University System of Georgia. GPC has over 27,000 students; it is the largest two-year college, the third largest school in the USG, and has the largest online program in USG (Georgia Perimeter College). GPC serves students looking for transfer opportunities, learning support, continuing education, online education, and joint educational offerings. GPC has 5 Atlanta area campuses and its students are increasingly getting younger (26 to 22) and transferring to other schools; the tuition at GPC (\$1,235 per semester) is significantly lower that other state institutions (Biemiller, 2011).

Georgia State University (1913) is a 4-year research doctorate-granting institution in downtown Atlanta. GSU has over 32,000 students ( $2^{\text {nd }}$ largest student body in Georgia), many of which are non-traditional, part-time, and commuter (Georgia State University). Initially 
established as a night school, GSU has rapidly expanded since its establishment by acquiring and constructing many buildings in downtown Atlanta. GSU contributes significantly to Atlanta's economy and has a high minority student population as it was named the institution awarding the most bachelor's degrees to African Americans (Georgia State University). GSU's student body aptly reflects the state of Georgia as $87 \%$ of students are on need-based financial aid, $40 \%$ receive Pell grants, $74 \%$ are on HOPE, and $30 \%$ of freshman come from households with annual incomes of $\$ 35,000$ or less (Georgia State University). Further, the graduating high school student population in Georgia is 39\% minorities and GSU's freshman class has 39\% under-represented minority groups (Georgia State University).

Agnes Scott College is a private, women's liberal arts college in Decatur, Georgia. In comparison to GPC and GSU, ASC is decidedly small ( 1,000 students), denominational (affiliated with the Presbyterian Church), focused on 4-year degrees (no other programs are offered), and suburban (with a sprawling, lush 90 acre campus); the school was the first in the state of Georgia to receive regional accreditation (Agnes Scott College). 86\% of ASC students live on campus, $21.4 \%$ of the class of 2016 graduated in the top 5\% of their class, the average class GPA was 3.61, and 70\% of students qualified for and received need-based financial aid; a long-standing honor code at ASC is held in high esteem and taken seriously (Agnes Scott College).

The socio-economic context in Atlanta (similar to national trends) is putting more pressure on schools to creatively navigate around funding cuts en route to maintaining quality educational offerings at reasonable costs while increasing student success. Similar to national trends, applications and enrollments are up at all three schools as individuals seek additional credentials that will hopefully provide them greater career opportunities. All of GPC's campuses, for example, have received elevated numbers of applications. Cognizant of the stress caused by the economic downturn, GPC has importantly provided students with personal counselors who help students manage money, stress, and anxiety (Biemiller, 2011). Some class sizes have increased at GPC and faculty raises have been delayed. Luckily unlike the national trend to expand contingent faculty and limit tenure-track faculty hires (Schuster, 2011), GPC has been able to use revenue from increased enrollment to hire 30 new tenure-track faculty, students will benefit from this (Biemiller, 2011).

GSU prides itself on enrolling minority and needy students; over half of GSU students receive Pell grants (Biemiller, 2011). Similar to GPC, GSU is being proactive about trying to help students during the recession. While the school cannot afford to help many students with additional institutional aid, school officials are contacting students (many of whom failed to pay tuition) in attempts to gauge their needs and help them find solutions to economic deficits (Biemiller, 2011). Similar to national trends, GSU students are working more hours and jobs to stay economically afloat (Renn \& Reason, 2012). At the federal level, student aid policies have been directed toward increasing access to higher education through direct aid to college students. The question as to whether the federal government should act to contain college costs is continuously controversial. While the federal government does provide most of direct student aid it only supplies $15 \%$ of college and university revenues thus leaving states and campuses to cost containment schemes (Mumper, Gladieux, King \& Corrigan, 2011, p. 134). 
Democrats and Republicans have very different visions for government involvement in higher education. Where Republicans are pushing to tighten eligibility for federal student aid, freeze the maximum Pell Grant at $\$ 5.645$ for the next ten years, and consolidate federal job-training programs Democrats hope to raise taxes and increase spending on education and research (Field, 2013). These differences indicate that federal student aid opportunities will revolve around a polarized political climate in the years to come. Regardless of whether students at any institution receive federal or local aid, financial assistance is only meaningful if it leads to increased student success.

At ASC the cost of tuition is relatively high $(\$ 42,000)$ but many students at the school pay much less due to a $61 \%$ in-house tuition discount rate (Biemiller, 2011). Since ASC is private, it depends more on revenues from tuition than do GSU and GPC. Because of this reality, ASC had to get creative in order to cut costs. This led to offering faculty members early retirement packages and launching a strategic plan that aimed to rely less on the endowment in favor of realigning revenues and expenditures (Biemiller, 2011). The strategic plan at ASC purposely aims to increase fundraising, increase marketing and grant-seeking capacity, and develop long-term financial and information technology plans; it is important to think long-term about securing funds and cutting costs (Agnes Scott College). Private schools are not less immune to a recession fall-out than private schools. ASC's endowment took a sizable hit and accordingly the school will have to advance a capital campaign, reduce its in-house discount rate, and encourage students to seek financial aid from external sources.

In terms of faculty issues, each of these intuitions must consider how to most efficiently hire and retain capable scholars in a way that aptly balances teaching and research. National trends indicate that contingent faculty members are being hired at much greater rates than tenure-track instructors. Indeed a new paradigm has emerged, one that Jack Schuster (2011) calls the "restratified university" (p. 8). Under this new arrangement full-time, non tenure-track academic appointments are the norm, tenure is under attack, and sharply differentiated compensation packages exist for faculty members according to institutional type and academic discipline (Schuster, 2011). Like all of the new arrangements within the new normal, these new faculty configurations are driven by economic uncertainty and fiscal constraints and by institutional attempts to optimize learning and prestige through the proliferation of research and interdisciplinarity (Geiger, 2010).

GPC was lucky to be able to hire 30 new tenure-track faculty members during the recession (Biemiller, 2011) but these hires do not shield the fact that many more contingent faculty members are being hired at the institutions especially to teach one of their extensive online course offerings. Large public institutions such as GPC and GSU are not immune from stacking their faculty rosters with contingent faculty members. In this economy faculty members are simply lucky to be employed. This is certainly true at GPC where the 550 full-time faculty members have not had a raise in the last four years and furlough days have been used (Biemiller, 2011). As tenure is increasingly difficult to come by and the large differentiation between salaries of tenure-track and non-tenure track faculty members, there is likely to be derision among the faculty ranks although in some cases it does appear that contingent faculty members are still optimistic that they will eventually land a tenure-track 
position (Berrett, 2012; Hebel, 2012). Despite the idea that higher education instructors are an optimistic lot, colleges and universities need to actively engage their faculty members to higher standards of teaching and research and also ask them to directly participate in initiatives to retain and graduate students. This is being done at GSU where initiatives encourage faculty members to use retention and graduation data to produce and implement annual departmental retention plans that are cognizant and responsive to particular disciplinary challenges (Georgia State University). This trend of asking faculty to do more is a nation-wide one.

At small, private institutions such as ASC faculty student ratios are likely smaller, classes are usually smaller, and accordingly full-time faculty appointments are scarcer. At ASC there are 72 full-time faculty members and all tenure-track faculty members hold a terminal degree (Agnes Scott College). These statistics invoke questions surrounding faculty quality. Since the college faculty market is saturated (with many PhD-holding applicants) almost every institution will have opportunities to boost their percentages of faculty members holding terminal degrees. However, the rise of contingent faculty members implores us to question, as Schuster (2011) points out, if these new normal faculty members are adequately qualified to teach (p. 14). Quantity will be there, but can instructor quality be measured during the new normal? This question will need to be answered by public and private intuitions alike.

In terms of institutional sectors, the contemporary context impacts these Atlanta schools differently according to private or public status yet there our underlying recession outcomes that impact these school similarly. For example, during a severe economic downturn fewer students can afford to attend college and fewer student loans are given out by banks. In addition, as resources dwindle at all levels of education students are increasingly underprepared for college which impacts their eventual prognosis of graduating and finding meaningful employment. Still further, a lack of jobs waiting for students during a recession may make students question if it is worth accumulating debt to attend college. Finally, as public funding for higher education dries and private endowments are reduced institutions in all sectors must look to practice creative frugality. By looking at the strategic plans of each of these three institutions an understanding as to how different sectors of higher education approach the recession can be gleaned.

GPC has a general mission to transform the lives of students to thrive in a global society. The school will supposedly achieve this by strengthening student success, fostering a culture of continuous improvement, enhancing the vitality of its community, and expanding access enrollment capacity (Georgia Perimeter College). In addition, the school is committed to organizational efficiency as suggested by a goal to increase resources and capital while remaining affordable and accessible to students while removing barriers to student success (Georgia Perimeter College). These are great yet very optimistic goals. The specifics as to how GPC will rectify its financial woes include swift executive decisions. For example, in the last year GPC has cut almost 200 employees, increased teaching loads, deferred IT maintenance, and witnessed the resignation of former president Anthony Tricoli in wake of a \$16-million deficit (Holdaway, 2012). Clearly GPC has opted to downsize, have current faculty members do more, and pursue more effective presidential leadership during the 
recession. Previous proclamations to not cut staff gave way to economic necessity. This fact indicates to me that GPC has reached its boiling point with the recession and that the school's finances were mismanaged. The school should consider instituting a new mechanism for financial oversight. Modest tuition increases across the USG demonstrate that the state is dedicated to maintaining affordability and access.

GSU faces several challenges that it will attempt to strategically address. These challenges include: attending to unmet need among the student body; helping students retain HOPE benefits; and tackling cross-university retention and graduation issues (Georgia State University). GSU's current strategic plan includes 5 goals: helping students achieve academic and career success at high rates; growing the base of graduate and professional programs; becoming a leading public research institution; providing solutions to the complex problems endemic to cities; and globalizing the university (Georgia State University). GSU will attempt to accomplish these goals by: doubling the level of institutional support for merit and need based scholarship funding; connecting students with a range of external scholarships; establishing a student success center to provide student academic support programs, lower the student/advisor ration, track each student's academic progress, and enhance faculty teaching; enhancing undergraduate experiences; enhancing a research culture; highlighting the arts and media; expanding support for doctoral programs; enhancing the global competency of students and staff; and establishing an honors college (Georgia State University). These initiatives are quite impressive and speak to the student-centered culture that GSU is trying to build. It seems that GSU's limited resources are being used to support students financially, programmatically, and occupationally. It also appears that GSU is dedicated to helping students understand their financial aid options and working hard to help students retain the benefits they are currently receiving from financial aid programs. GSU appears dedicated to creating a tracking system to more meaningfully assess persistence and graduation rates by creating a system-wide 6-year graduation rate that does not count transfers within the USG system as graduation or retention casualties. Thus, institutional priorities at GSU acknowledge dwindling state support and seek to make the most of institutional funds, retain current student benefits, and expand programs to enhance student experiences and success.

As a private institution, ASC is able to give additional financial aid to students from its own coffers. While private schools may be more expensive based on sticker price they also give more financial aid to mitigate the cost. ASC's strategic plan involves: creating a center for women's global leadership; enhancing the liberal arts curriculum; engaging students in co-curricular learning opportunities; living honorably; and "smart growth" through increasing enrollment and retention, enhancing fundraising and grant-seeking capacity, and launching a comprehensive campaign (Agnes Scott College). The Agnes Scott Solution, for example, provides merit awards of $\$ 15,000$ annually to students with a 3.6 GPA and 1300 SAT score or 29 ACT score. ASC's tuition discount rate is a major incentive to attract students. In addition, the college's ability to limit tuition increases to 3\% can help students understand and better prepare financially. ASC has also focused on making sound investments to preserve its endowment, increasing its alumnae giving rate which impressively hovers around 50\%, and increasing private donor support to meet a \$100 million campaign (Agnes Scott College). 
These goals indicate that ASC is squarely focused on keeping its financial house in order. By aligning revenues with expenditures, relying less on its endowment, and marketing itself outside of Georgia ASC is responsibly positioning itself to mitigate damages resulting from the recession.

\section{The H.O.P.E. Scholarship}

A major issue undergirding an analysis of the three Atlanta institutions in relation to each other and the national higher education context should begin with a discussion of changes to the HOPE (Helping Outstanding Pupils Educationally) financial aid program and how these changes have and will likely impact students at the three institutions. The Georgia HOPE scholarship (created in 1993 under the supervision of Georgia Governor Zell Miller), funded by the Georgia lottery and administered by the Georgia Student Finance Commission, provides financial assistance to students attending Georgia public and private colleges and universities. HOPE is an entirely merit-based scholarship and grant program that rewards students with financial assistance in degree, diploma, and certificate programs. The scholarship is awarded to undergraduate students who: graduated from an eligible high school in 1993 or later with a 3.0 GPA or better in a college preparatory track or a 3.2 GPA in a technical curriculum track; completed a HOPE eligible home study program with a 3.0 GPA; scored in the national composite $85^{\text {th }}$ percentile or higher on the ACT or ACT tests; graduated from an ineligible high school and then earned a 3.0 GPA on 30 semester hours or 45 quarter hours of college degree-level coursework; and earned a 3.0 GPA at the college-level on degree coursework after attempting 30, 60, or 90 semester hours or 45, 90, or 135 quarter hours, regardless of high school graduation status. In addition to these requirements, students must meet citizenship and residency requirements, not be in default on a student financial aid program, and meet satisfactory rigor and academic progress standards as set by a particular college (Georgia Perimeter College). The program has been wildly popular and successful in its attempt to assist poor academically superior students and keep affluent academically successful students from leaving the state for college. However, changes to the HOPE program in 2011 have brought about criticism. As the HOPE program faced economic challenges, participation was cut and benefits were reduced to save the program. Changes to the HOPE program state that $90 \%$ of a student's tuition will be covered (instead of all tuition), books and fees will no longer be paid for, students must maintain a 3.0 GPA throughout their college career to retain benefits, learning support classes will not be paid for, students with a bachelor's degree are no longer eligible for HOPE benefits, and the scholarship will be adjusted annually based on litter revenue (TCSG, 2013). Previous HOPE students were not grandfathered into the new program system. A new Zell Miller Scholarship was created that does cover $100 \%$ tuition, books, and fees but it requires that students have a 3.7 GPA from an eligible high school and a combined 1200 SAT score or 26 ACT score and maintain a 3.3 GPA (TCSG, 2013).

The implications of the new more stringent HOPE qualifying standards for Georgia's colleges are significant. The HOPE situation can be viewed as a microcosm of the new normal 
predicament although it is debatable as to whether Georgia has done more with less in this case. The recession has drained HOPE's reserves and now fewer students will qualify for HOPE scholarships. In addition, HOPE cuts mean that many students must come up with extra money to cover what HOPE would have paid; students are taking out additional loans or working more to make up the difference (Biemiller, 2011). Criticisms of new HOPE stipulations have been various. For one, the removal of applicant income caps might increase student participation but may also end up helping affluent students who are not in dire need of financial assistance. Since there is a positive correlation between socio-economic status and academic success, raising GPA and test score requirements may only secure scholarships for the economic elite (Quizon, 2011; Stripling, 2010). Since affluent students would likely be able to pay for college out-of-state, will economic incentives to stay in Georgia likely prevent a brain drain? Secondly, HOPE has been criticized as a program that is subsidized by the poor since the lottery (the source of HOPE's funding) is disproportionately supplied by poorly educated, low-income African Americans and scholarships are more likely to be awarded to counties with higher per capita incomes (Stripling, 2010). Although HOPE does appear to increase enrollment rates this can only be considered a penultimate achievement since it is too early to tell if new requirements will lead to increased attainment. A concern related to the GPA requirement is that schools might be tempted to "pump-out" more " $\mathrm{B}$ " high school students in order to make students eligible for the scholarships. Will grade inflation become more prevalent? This last point invokes an academic pipeline issue as high school grade inflation and the inability of schools in underserved areas to prepare students for college will likely mean that disadvantaged students will not be positioned to receive HOPE scholarships. Finally, minority HOPE scholarship recipients (particularly African-Americans) are significantly less likely to retain their scholarships than their peers of other ethnicities (Grasgreen, 2012). This reality is of particular importance to GPC, GSU, and ASC as all three schools have high African-American enrollment numbers. Certainly students must take responsibility for their academic performance but colleges can enact initiatives (faculty-led work groups, community learning programs, additional in-house funding etc.) that purposely aim to help students retain their HOPE money and graduate (Grasgreen, 2012).

Under new HOPE guidelines, these three Atlanta-based colleges will decidedly benefit from configuring plans aimed at helping current HOPE scholars pay for the tuition and fees coverage that has been discontinued and retain their scholarships year-in and year-out. This can be done in many ways. For example, some colleges have developed local and community financial assistance plans to help students who can't afford the extra tuition and book costs and identify avenues to low-cost loan programs for students in need (TCSG, 2013). Another suggestion is to provide in-depth counseling to HOPE scholars which would guide them to stay on track to retain benefits. A final suggestion would be to create alliances between institutions of higher education and secondary schools that guide Georgia high school students to optimally understand how to qualify for and maintain HOPE funding. Such sessions could also help students understand that other need-based financial aid programs such as Pell grants can be combined with HOPE scholarship awards. Whatever the case may be, all efforts toward helping students secure financial assistance to attend college should be predicated on the philosophy that students must take primary responsibility for their own 
academic successes and failures and that access into college has little meaning without completion and meaningful postgraduate placement.

\section{Conclusion}

In conclusion, the current plights of GPC, GSU, and ASC can be connected to the broader context of the new normal in higher education. This new context for colleges and universities includes a decisive shift in the nature and control of higher education in America. As government support for public institutions wanes and schools increasingly privatize it is incumbent upon schools to reassess where they stand in the higher education landscape and implement initiatives that maintain quality without greatly diminishing access and affordability. New realities must be understood: state funding to higher education will continue to be strained; schools will need to find funding from alternative sources such as corporate sources and decipher an appropriate balance between merit- and need-based aid; as student-debt increases, the rate of tuition increase will need to slow; schools will need to become increasingly transparent about their costs; diversity and globalization will continue to remain institutional imperatives for all school types; teaching and research will need to be optimally balanced; the access debate will need to shift to a completion debate; and overall, public institutions and state governments will need to forge revised relationships with each other based on mindful cross-considerations of institutional accountability and autonomy.

As public institutions, GPC and GSU will need to reassess their relationship with the Georgia government (USG). These schools will need to increasingly consider the pros and cons of decentralization and privatization. While privatization means less state funds for schools, it also means that institutions will be able to make quicker and easier decisions about important issues and presidents will have more freedom to invest in good ideas (MacTaggart, 1998). This increased freedom to choose can be a blessing or a curse depending on the capabilities of a particular leader. Privatization means that institutions must hire competent leaders who embody the values of the college, leaders who know how to raise funds and understand that external bureaucratic structures will be replaced by market forces and student needs. Public institutions such as GSU and GPC must come to assess how they can develop relationships with state governments in ways that maintain procedural autonomy for themselves yet delegate substantive autonomy to state authorities. These schools should aim to sever their relationship with the state but to clearly redefine it within the context of the new normal condition of higher education. Private institutions such as ASC already have the ability to set their own mission and financial agendas without extensive external interference. However, ASC's private status does not render it immune to the ills of the economic downturn. Private colleges must also consider how they can continue to maintain quality academic offerings through endowment losses and become economic, intellectual, and social engines for their communities and the nation at large. Private institutions must continue to graduate students at high rates and be mindful of technological and demographic realities en route to creating diverse and stimulating academic environments. During an economic recession there is no comfort for public or private intuitions of higher education, however, any intuition that 
understands and proactively addresses the tenets of the new normal in higher education is on track to position itself to operate efficiently and effectively in the current context.

\section{Acknowledgement}

This research was inspired by Dr. Sorber at West Virginia University.

\section{References}

$\begin{array}{lllll}\text { Agnes } & \text { Scott } & \text { College. } & \text { (2013). } & \text { Retrieved }\end{array}$ http://www.aacu.org/about/statements/academic_freedom.cfm

American Association of State Colleges and Universities. (2012, January). Top 10 higher education state policy issues for 2012. Retrieved from http://www.aascu.org/uploadedFiles/AASCU/Content/Root/PolicyAndAdvocacy/Policy Publications/Policy_Matters/Top_Ten_State_Policy_Issues_2012.pdf

Atlanta Business Chronicle. (2011, November 9). Atlanta fourth-highest in recession job losses. Retrieved

from http://www.bizjournals.com/atlanta/news/2011/11/09/atlanta-fourth-highest-in-recession .html

Baum, S. (2012, November 5). How tough love can ensure the future of pell grants. The Chronicle of Higher Education. Retrieved from http://chronicle.com/article/Tough-Love-to-Ensure-the/135518/

Baum, S. \& McPherson, M. (2011, January 18). Is education a public good or a private good? The Chronicle of Higher Education. Retrieved from http://chronicle.com/blogs/innovations/is-education-a-public-good-or-a-private-good/28 329

Berrett, D. (2012, October 24). Today's faculty: Stressed, focused on teaching, and undeterred by long odds. The Chronicle of Higher Education. Retrieved from http://chronicle.com/article/Todays-Faculty-Stressed-and/135276/

Biemiller, L. (2011, October 23). Atlanta colleges strive to outrun the recession. The Chronicle of Higher Education. Retrieved from http://chronicle.com/article/article-content/129487/

Field, K. (2013, March 12). In 2014 budgets, republicans and democrats offer competing plans for academe. The Chronicle of Higher Education. Retrieved from http://chronicle.com/article/In-2014-Budgets-Republicans/137871/?cid=at\&utm_source =at\&utm_medium=en

Geiger, R. L. (2010). Optimizing research and teaching: The bifurcation of faculty roles in research universities. In J.C. Hermanowicz (Ed.), The American academic profession: 
transformation in contemporary higher education. Baltimore: Johns Hopkins University Press.

Gelber, S. (2007, October). Pathways in the past: Historical perspectives on access to higher education. Teachers College Record, 109(10), 2252-2286. http://www.tcrecord.org/library/content.asp?contentid=12566

Georgia Perimeter College. (2013). Retrieved from http://www.gpc.edu

Georgia State University. (2013). Retrieved from http://www.gsu.edu

Goldrick-Rab, S., \& Cook, M.A.E. (2011). College students in changing contexts. In P.G. Altbach, R.O. Berdahl, and P.J. Gumport, (eds.), American Higher Education in the Twenty-First Century: Social, Political, and Economic Challenges (3rd ed.). (pp. 279-311). Baltimore: The Johns Hopkins University Press.

Grasgreen, A. (2012, August 31). Lost HOPE. Inside Higher Education. Retrieved from http://www.insidehighered.com/news/2012/08/31/low-income-black-students-low-acade mic-achievement-least-likely-retain-state-lottery

Hebel, S. (2012, August 26). Presidents and faculty try to keep pace with shifting values. The Chronicle of Higher Education. Retrieved from http://business.highbeam.com/434953/article-1G1-302048740/presidents-and-professors -tumultuous-year

Holdaway, X. (2012, May 25). Georgia Perimeter College to cut almost 200 employees. The Chronicle of Higher Education. Retrieved from http://chronicle.com/blogs/ticker/georgia-perimeter-college-to-cut-almost-200-employee s/43601

Kinser, K. (2006). From main street to Wall Street: The transformation of for-profit higher education. San Francisco: Jossey-Bass.

MacTaggart, T.J. (1998). Seeking excellence through independence: Liberating colleges and universities from excessive regulation. San Francisco: Jossey-Bass Publishers.

McGuinness Jr., A.C. (2011). The states and higher education. In P.G. Altbach, R.O. Berdahl, and P.J. Gumport, (eds.), American Higher Education in the Twenty-First Century: Social, Political, and Economic Challenges(3rd ed.). (pp. 139-169). Baltimore: The Johns Hopkins University Press.

Mumper, M., Gladieux, L.E., King, J.E. \& Corrigan, M.E. (2011). The federal government and higher education. In P.G. Altbach, R.O. Berdahl, and P.J. Gumport, (eds.), American Higher Education in the Twenty-First Century: Social, Political, and Economic Challenges, 3rd ed. (pp. 113-138). Baltimore: The Johns Hopkins University Press.

Quizon, D. (2011, February 22). Plan to save Georgia’s HOPE scholarships would link awards to grades. The Chronicle of Higher Education. Retrieved from http://chronicle.com/article/Plan-to-Save-Georgias-Hope/126478/ 
Renn, K.A., \& Reason, R.D. (2012). College Students in the United States: Characteristics, experiences, and outcomes. Hoboken, NJ: Jossey-Bass.

Ruch, R.S. (2001). Higher Ed. Inc.: The rise of the for-profit university. Baltimore: Johns Hopkins University Press.

Schmidtlein, F.A., \& Berdahl, R.O. (2011). Autonomy and accountability: Who controls academe? In P.G. Altbach, R.O. Berdahl, and P.J. Gumport, (eds.), American Higher Education in the Twenty-First Century: Social, Political, and Economic Challenges, 3rd ed. (pp. 69-87). Baltimore: The Johns Hopkins University Press.

Schuster J. H. (2011). The professoriate's perilous path. In Hermanowicz J. C. (Ed.), The American academic profession. Transformation in contemporary higher education (pp. 1-20). Baltimore, MD: The Johns Hopkins University Press.

Smith, D.G. (2011). The diversity imperative: Moving to the next generation. In P.G. Altbach, R.O. Berdahl, and P.J. Gumport, (eds.), American Higher Education in the Twenty-First Century: Social, Political, and Economic Challenges, 3rd ed. (pp. 465-490). Baltimore: The Johns Hopkins University Press.

State Higher Education Executive Officers Association. (2011). State higher education finance $\quad$ FY 2011. Retrieved from http://www.sheeo.org/sites/default/files/publications/SHEF_FY11.pdf

Stripling, J. (2010, September 21). Losing HOPE. Inside Higher Education. Retrieved from http://www.insidehighered.com/news/2010/09/21/hope

Technical College System of Georgia. (2013). Retrieved from https://tcsg.edu/hope.php

Zusman, A. (2005). Challenges facing higher education in the twenty-first century. In P. G. Altbach, R. O. Berdahl, \& P. J Gumport (Eds.), American higher education in the twenty-first century. ( $2^{\text {nd }}$ ed., pp. 115-160). Baltimore: The Johns Hopkins University Press.

\section{Copyright Disclaimer}

Copyright reserved by the author(s).

This article is an open-access article distributed under the terms and conditions of the Creative Commons Attribution license (http://creativecommons.org/licenses/by/3.0/). 